\title{
PROSPECTS OF RENEWABLE ENERGY RESOURCES AND REGIONAL GRID INTEGRATION FOR FUTURE ENERGY SECURITY \& DEVELOPMENT IN SAARC COUNTRIES
}

\author{
T. H. M. Sumon Rashid ${ }^{1}$, Md. Rabiul Islam ${ }^{2}$ \\ ${ }^{1,2}$ Lecturer, Department of Electrical and Electronic Engineering, Pabna Science and Technology University, Pabna, \\ Bangladesh,sumon05eee@gmail.com,mrabiul_eee_eng@hotmail.com
}

\begin{abstract}
Everyday Energy shortage rewinds the growth of economic development, gradually situation become more severe with the increasing electricity shortage, countries are worried about future energy security due to scarcity and environmental impacts of fossil fuels become apparent. Renewable Energy sources (solar, wind, hydro and biomass) are becoming a more important energy option in the future generation systems. Investment to Hydro Power and Regional Grid interconnection may be proper step to meet up in a significant amount for future regional energy security in SAARC Countries. In this paper a neat demonstration will be given on how regional Grid interconnection and hydropower system helps to build in Sustainable regional energy security among SAARC countries. A detailed research on the prospect of Grid Interconnection and hydropower resource for regional energy security was done during the period June-November, 2012 at Pabna Science and Technology University (PSTU).
\end{abstract}

Index Terms: Energy security, Sustainable energy, Grid interconnection, Hydro power, SAARC $* * * * *$

\section{INTRODUCTION}

The overall Power need for South Asian countries are predicted to be three times that of today within the next 15 to 20 years. Since, this region is unevenly endowed with natural resources it may lead serious hazards in Power sector as well as economic development, if not proper steps are taken right now.

The uneven spatial distribution of natural resources in South Asia has created a need for regional cooperation. The region is very poor in oil reserves-less than 0.5 percent of the world's oil resources are located in the region. While there is broad agreement that energy needs in most South Asian countries are not met under the current setting, the question remains why energy trade has been lagging behind for decades. [1]

Regional cooperation means the building up of competition between local and regional power providers by opening up markets to a selected set of member countries. Regional energy cooperation can also be understood in the context of knowledge exchange and economies of scale in decentralized rural electrification [1]. In South Asia, regional practices or agreements on regional electricity have not been implemented so far. Instead there are a number of historical experiences on a bilateral basis between India and its northern neighbours Bangladesh, Bhutan and Nepal.

Singh (2009) claims that pressure for energy cooperation is increasing due to the following exogenous socio-economic conditions: rising urbanization; increasing dependence on fossil fuel imports from the Middle East; vulnerability to external shocks and price volatility; low access to electricity; lack of hydropower markets in countries with excess hydropower like Bhutan and Nepal.

Cross-border power Grid Integration will produce measurable benefits:

a) Effective utilization of natural resources;

b) Increase in reliability of power supply;

c) Economy in operation and mutual support during contingencies;

d) Large-scale transformation in the sectors contributing to economic growth;

e) Single most effective building measure through the participation of multiple stakeholders;

f) Regional energy security through fuel diversification and a regional power grid;

g) Benefits from seasonal differential demands;

h) Technological transfer and human resources development;

i) Regional based practices to reduce environmental hazards.

Hydro power is a potential source of sustainable green energy. Most of the SAARC countries have potential resources of Hydro power. Mainly Nepal and Bhutan have a huge amount of resource of Hydro power. Unfortunately, most of this valuable resources remaining unused due to lack of proper steps, financial arrangements, technical knowledge etc. If it is possible to use this resource by overcome such problems by mutual cooperation among SAARC countries and making 
Grid integration, this sector of renewable energy source can contribute largely in future energy security and economic growth in SAARC countries.

\subsection{Background}

SAARC consists of eight developing countries (Bangladesh, Nepal, India, Pakistan, Sri-Lanka, Bhutan, Maldives and Afghanistan). Although, some countries have huge energy resources with shortage demand and some have shortage of resources with larger demand, after that every country facing serious energy shortage due to lacking of technical knowledge, proper planning, and financial limitation.

Due to power shortage a country wants to import power from neighbouring countries and due to surplus power a country wants to export power to other countries. For the above reasons, countries are going for interconnection .i.e. the power system interconnection plans have been proposed and are in progress in several regions in Europe, North America, Africa, South-East Asia, Central America etc. For power exporting countries, income from power sales is a key economic advantage of power grid interconnections and for power importing countries they are able to minimize power shortage. As an Example, Nordic countries interconnection (NORDEL) which includes the electric utilities in Scandinavian countries involving $2.8 \%$ of the world installed capacity and covers an area of about 1.23 million $\mathrm{km} 2$. NORDEL system is connected with UCPTE (Union for the cooperation of Production and Transmission of Electricity) and UPS (The United Power System) systems via DC links [2].

Like Nordic and Scandinavian countries SAARC countries also use regional grid interconnection to meet up energy shortage and improve economic development.

\section{RESEARCH GOAL}

The Goals of this paper is to serve a reliable source for the policy makers to understand the potentiality of renewable energy resource of South Asian region and show a guide lines how these resources can help to build a space of Sustainable economic growth in this region. More specifically it aims to:

A) To assess the prospect of overall renewable energy resource (mainly Hydro).

B) Draw on the experience of successful regional energy cooperation and prospects of regional Grid interconnection.

C) Analysis and suggest the suitable Method of Power Grid Integration.

D) Probable Cost benefits analysis of interconnected countries after Grid Integration.

\section{COUNTRY WISE RENEWABLE ENERGY POTENTIAL}

\section{A. Bangladesh}

The scope of hydropower generation is very limited in Bangladesh. The country is mostly flat, except for some hilly regions in the northeastern and southeastern parts. The country's only hydropower plant at Kaptai with installed capacity is only $230 \mathrm{MW}$ depending on the water flow it can be up to $350 \mathrm{MW}$. Due to the country's flat terrain and potentially large social and environmental impacts only smallscale exploration is likely in the future. But all over the Bangladesh Average solar radiation varies between 4 to 6.5 $\mathrm{kWh} \mathrm{m}$-2day-1. Maximum amount of radiation is available on the month of March-April and minimum on DecemberJanuary. The total renewable energy resources summary of Bangladesh listed in Table-1.

Table -1: Estimated Renewable Energy Potential in Bangladesh. [3][4][9]

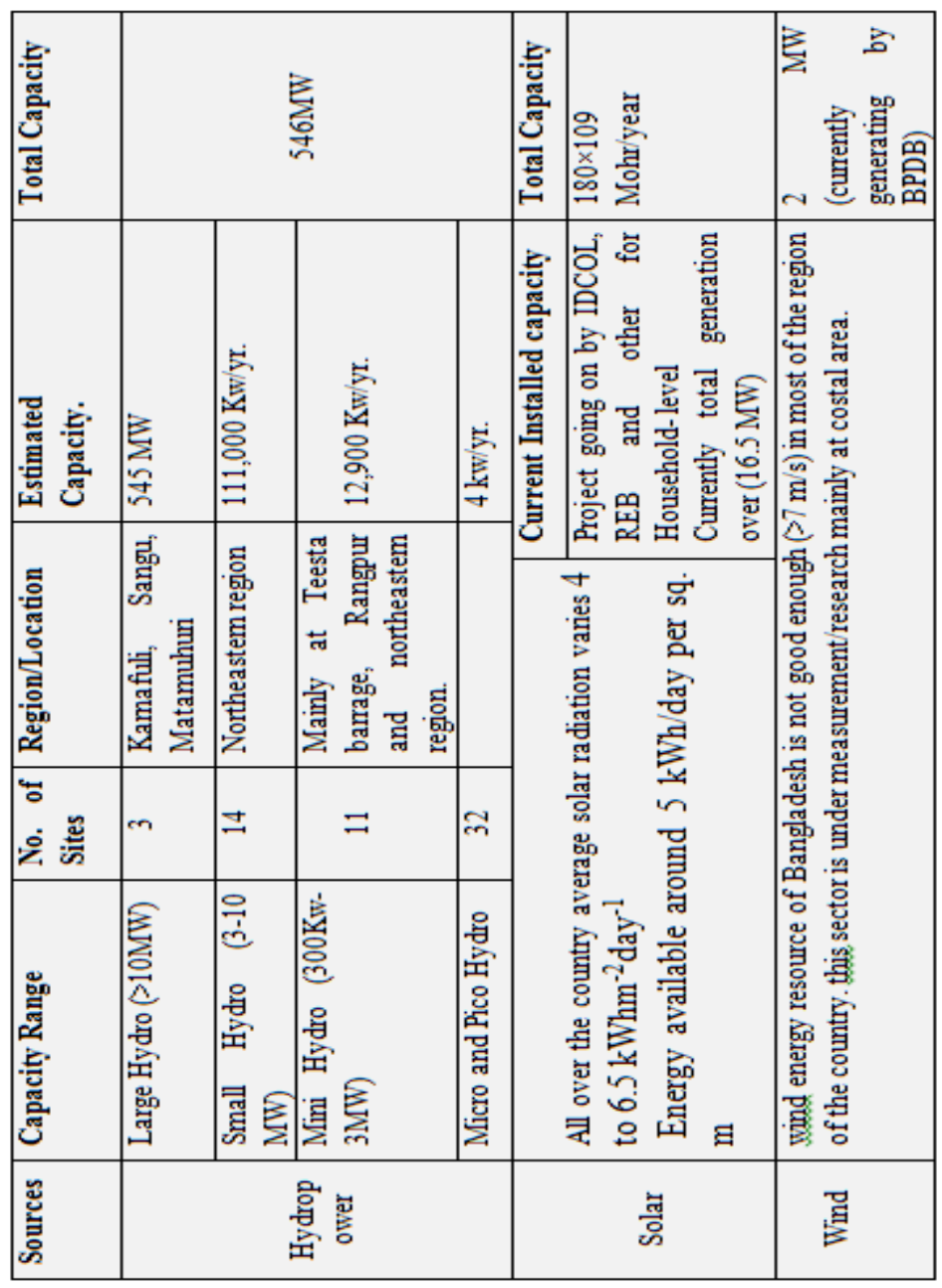




\section{B. Bhutan}

Bhutan has huge Hydropower potential. Hydropower aside, the country has no proven gas, oil or coal reserves. This means Bhutan is importing all of its petroleum product requirements. Hydropower is the largest renewable energy sources in Bhutan. Hydro power, the source for $99 \%$ of the country's electricity generation today is widely abundant in terms of hydropower potential estimated at $60,000 \mathrm{MW}$. However, the total hydroelectric potential technically exploitable capacity based on all practicable sites for head development and assuming average water flow is estimated at 23,500 MW [5]. The total estimated Renewable energy resources of Bhutan are given in Table-2.

Table -2: Estimated Renewable energy resources in Bhutan. [5]

\begin{tabular}{|c|c|c|}
\hline $\begin{array}{c}\text { Resourc } \\
\text { es }\end{array}$ & Installed capacity & $\begin{array}{l}\text { Estimated } \\
\text { Capacity }\end{array}$ \\
\hline $\begin{array}{l}\text { Hydro } \\
\text { power }\end{array}$ & $6,720 \mathrm{MW}$ & $60,000 \mathrm{MW}$ \\
\hline Wind & $\begin{array}{l}\text { Most of the site have } \\
\text { wind speed }>7 \mathrm{~m} / \mathrm{s}\end{array}$ & $350,000 \mathrm{MW}$ \\
\hline Solar & $\begin{array}{l}\text { Pakistan receives solar } \\
\text { energy intensity in the } \\
\text { sun belt is } \\
\text { approximately } 1,800 \text { - } \\
2,200 \mathrm{KWh} \text { per sq. } \mathrm{m} \\
\text { with an annual } \\
\text { sunshine duration of } 8 \\
\text { to } 8.5 \text { hours. }\end{array}$ & $100,000 \mathrm{MW}$ \\
\hline \multirow[t]{2}{*}{ Biomass } & $\begin{array}{l}\text { Annual biogas } \\
\text { production }\end{array}$ & $\begin{array}{c}\text { Annual } \\
\text { estimated } \\
\text { electricity } \\
\text { production }\end{array}$ \\
\hline & $\begin{array}{l}8.8 \text { to } 17.2 \text { billion } \\
\text { cubic meters }\end{array}$ & 55 to $106 \mathrm{TWh}$ \\
\hline
\end{tabular}

\section{Nepal}

Nepal has a huge hydropower potential. In fact, the perennial nature of Nepali rivers and the steep gradient of the country's topography provide ideal conditions for the development of some of the world's largest hydroelectric projects in Nepal. Current estimates are that Nepal has approximately 45,610 MW of economically feasible hydropower potential. In spite of having a huge hydropower potential, Nepal has not been able to harness this natural resource due to various reasons including constraints of financial and human resources. However, the present situation is that Nepal has developed only approximately $689 \mathrm{MW}$ of hydropower. Therefore, bulk of the economically feasible generation has not been realized yet. Besides, the multipurpose, secondary and tertiary benefits have not been realized from the development of its rivers. The total estimated Renewable Energy resources of Nepal listed in Table-3.
Table -3: Estimated Renewable energy resources in Nepal. [6][7]

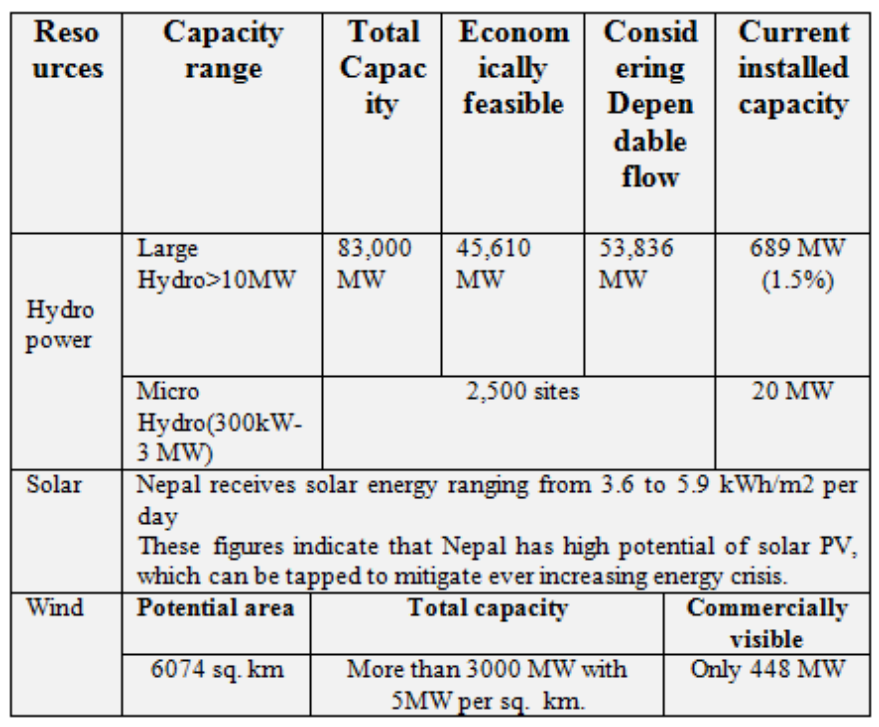

\section{Sri-Lanka}

The solar power is the largest renewable energy source in terms of quantity in Sri-Lanka. Besides Probability of large electricity production from renewable resource is not possible in Sri-Lanka due to lower capacity. The total estimated renewable energy resources of Sri-Lanka listed in Table-4.

Table -4: Theoretical Potential of the Renewable Energy Resources.

\begin{tabular}{|c|c|}
\hline $\begin{array}{c}\text { Type of the Energy } \\
\text { Source }\end{array}$ & $\begin{array}{c}\text { Estimated Quantity } \\
\text { (KTOE/year) }\end{array}$ \\
\hline Biomass & 16,000 \\
\hline Hydro power & 360 \\
\hline Solar power & 8600,000 \\
\hline Wind Power & 3,440 \\
\hline
\end{tabular}

\section{E. India}

The Global Wind Energy Council in its report - " Indian Wind Energy Outlook 2009" estimates that there is a potential of around 90,000 MW for power generation from different renewable energy sources in the country, including 48,561 MW of wind power, 14,294 MW of small hydro power and 26,367 MW of biomass. In addition, the potential for solar energy is estimated for most parts of the country at around 20 MW per square kilometer of open, shadow free area covered with solar collectors, which would add to a minimum of 657 GW of installed capacity. The total estimated renewable energy resources of India listed in Table-5. 
Table -5: Estimated Renewable energy resources in India. [8][11]

\begin{tabular}{|c|l|c|}
\hline Resources & Capacity range & Total Capacity \\
\hline \multirow{3}{*}{ Hydro power } & Large Hydro & MW \\
\cline { 2 - 3 } & Pumped storage & $94,000 \mathrm{MW}$ \\
\cline { 2 - 3 } & $\begin{array}{l}\text { Small, mini and } \\
\text { micro }\end{array}$ & $6,782 \mathrm{MW}$ \\
\hline Wind & & $48,561 \mathrm{MW}$ \\
\hline Biomass & & $26,367 \mathrm{MW}$ \\
\hline Solar & Potential area & $\begin{array}{c}\text { Generating } \\
\text { Capacity }\end{array}$ \\
\cline { 2 - 3 } & $\begin{array}{c}\text { Most part of the } \\
\text { country }\end{array}$ & \begin{tabular}{c}
$657 \mathrm{GW}$ \\
\hline
\end{tabular} \\
\hline
\end{tabular}

\section{F. Pakistan}

Pakistan is a country having abundant hydropower resources and the Government is keenly facilitating private investors to promote hydropower generation in the Country. Pakistan is endowed with hydropower resources of about $60000 \mathrm{MW}$. Pakistan, being on the Sun Belt, is highly suitable for generation of electricity through solar. Global irradiation falling on the horizontal surface is about $1,800-2,200 \mathrm{kWh} / \mathrm{m} 2$ per year. At current efficiency levels of $18 \%$ for solar modules this is sufficient to produce 0.320 to $0.400 \mathrm{MWh}$ of electricity per $\mathrm{m} 2$ per year.

The total estimated renewable energy resources of Pakistan listed in Table- 6 .

Table -6: Estimated Renewable energy resources in India. [8][11]

\begin{tabular}{|c|c|c|}
\hline $\begin{array}{l}\text { Resourc } \\
\text { es }\end{array}$ & Installed capacity & $\begin{array}{l}\text { Estimated } \\
\text { Capacity }\end{array}$ \\
\hline $\begin{array}{l}\text { Hydro } \\
\text { power }\end{array}$ & $6,720 \mathrm{MW}$ & $60,000 \mathrm{MW}$ \\
\hline Wind & $\begin{array}{c}\text { Most of the site have wind } \\
\text { speed }>7 \mathrm{~m} / \mathrm{s}\end{array}$ & $350,000 \mathrm{MW}$ \\
\hline Solar & $\begin{array}{l}\text { Pakistan receives solar } \\
\text { energy intensity in the sun } \\
\text { belt is approximately } \\
1,800-2,200 \mathrm{KWh} \text { per sq. } \\
\mathrm{m} \text { with an annual sunshine } \\
\text { duration of } 8 \text { to } 8.5 \text { hours. }\end{array}$ & $100,000 \mathrm{MW}$ \\
\hline \multirow[t]{2}{*}{ Biomass } & $\begin{array}{l}\text { Annual biogas } \\
\text { production }\end{array}$ & $\begin{array}{c}\text { Annual } \\
\text { estimated } \\
\text { electricity } \\
\text { production }\end{array}$ \\
\hline & $\begin{array}{c}8.8 \text { to } 17.2 \text { billion cubic } \\
\text { meters }\end{array}$ & 55 to $106 \mathrm{TWh}$ \\
\hline
\end{tabular}

\section{METHODOLOGY OF GRID}

\section{INTERCONNECTION}

International trading of electricity is not a new concept. International power grid networks already exist in many regions including Europe, North and South America, and South Asia. These cross-national border interconnections were developed for various reasons, and designed to provide benefits such as lowering of electricity production costs among the regional trading partners, increasing the quality and reliability of electricity service, reduction of the level of required reserve capacity in the connected grids, and improvements in national energy security.

National wide and international interconnection is a general tendency of modern power systems worldwide. It is well known that interconnections of power grids can produce many benefits to the involved parties, and some of the main benefits can be summarized as: [10]

i. Export of electricity from a country with surplus supply to another country with energy deficiency. Both countries can benefit from such an electricity transaction.

ii. Utilization of most favorable energy resources. This will be helpful for the sustainable.

iii. Economic development of the resources in the involved countries.

iv. Use of larger and more economical power plants.

v. Flexibility of building new power plants at favorable locations. Interconnections can lead to environmental benefits by sufficiently utilizing green energy among these countries, and hence avoiding the production of high pollution coal-fired generating plants.

vi. Sharing generation to take advantage of noncoincidental load demand.

vii.Cost reduction through joint economic dispatch and coordination of hydro and thermal resources among these countries.

viii. Improvement of supply reliability with emergency support from the neighboring grids.

\subsection{Factors of Regional Grid Interconnection}

\section{A. Unbalance Natural resource}

Most of the SAARC countries have Good natural energy resource, but unequally distributed due to geographical locations. Some of countries have huge energy resource than their current demand and still most of these resources remain idle while there is a huge power shortage in other high power demanded neighbouring countries. Country wise economically feasible resource (Hydro) in MW listed in Table-7. 
Table -7: Comparative table of Hydro power

\begin{tabular}{|c|c|}
\hline Country & $\begin{array}{c}\text { Economically feasible } \\
\text { resource (Hydro) } \\
\text { MW }\end{array}$ \\
\hline Bhutan & 23,500 \\
\hline Nepal & 45,610 \\
\hline Bangladesh & 546 \\
\hline India & $1,48,700$ \\
\hline Pakistan & 60,000 \\
\hline
\end{tabular}

\section{B. Energy Security}

One of the major driving forces for the interconnection of a power grid in SAARC Countries would be the improvement of the energy security in the region, including enhancing the reliability of electricity supply in each country by making available an international source of emergency backup power. Despite the recent economic crisis, the electricity demand in South Asia is expected to grow rapidly. As the region as a whole has relatively small oil and gas reserves, the economic growth and stability of this region now totally depend on Oil and gas import. Since, the environmental impacts of fossil fuel become apparent the future energy security totally depends on regional Grid connected renewable energy resource (Hydro, wind, Solar).

\section{Environmental Issue}

Air pollution is a significant concern in South Asia at both the local and trans-national-boundary levels. The rise in $\mathrm{CO} 2$ emissions and its environmental impacts from South Asia in recent years has caught the attention of not only environmental scientists but also energy policy makers in this region. Regional Grid integration is the solution of sharing clean energy among SAARC countries and economic development.

\section{Political Security}

Grid connections between the SAARC countries could improve the political security situation in the region. Arrangements for the pricing of internationally-traded electricity, for example, could catalyze the improvement of political security, since pricing is generally based on information provided by both parties and on considerable negotiation. Trust and the extensive exchange of detailed information about generation, transmission, and distribution costs would be required for the fair trade of electricity. Through the pricing negotiation process, the political security between the trading countries may be improved. Other collaborative efforts for developing and modeling the power grid infrastructure and implementing power exchange procedures and protocols could potentially also serve to render the regional political situation more secure.

\subsection{Method of grid integration}

Electricity grid interconnections have played a key role in the history of electric power systems. Improved transmission technologies, long distance interconnections developed, sometimes crossing national borders. The first international interconnections in Europe came in 1906, when Switzerland built transmission links to France and Italy.

Two types of Grid interconnection possible:

\section{A. HVAC System}

One of the great engineering achievements of the last century has been the evolution of large synchronous alternating current (AC) power grids, in which all the interconnected systems maintain the same precise electrical frequency. Today, the North American power system is composed of four giant synchronous systems, namely the Eastern, Western, Texas, and Quebec interconnections. The Eastern interconnection by itself has been called the largest machine in the world, consisting of thousands of generators, millions of kilometers of transmission and distribution lines, and more than a billion different electrical loads. Synchronous interconnections among countries are expanding in Central and South America, North and Sub-Saharan Africa, and the Middle East.

\section{B. HVDC System}

At the same time that synchronous AC networks have reached the continental scale, the use of high voltage direct current (HVDC) interconnections is also rapidly expanding as a result of technical progress over the last two decades. HVDC permits the asynchronous interconnection of networks that operate at different frequencies, or are otherwise incompatible, allowing them to exchange power without requiring the tight coordination of a synchronous network.

HVDC is used in interconnection projects in three principal applications:

\section{Transmitting large amounts of power over very long distances.}

Unlike long-distance AC transmission, HVDC transmission over long distances has no inherent stability limit. Also, even within AC stability limits (which can be extended through the use of FACTS or other reactive compensation), HVDC can overtake AC on cost grounds alone. This is because HVDC carries more power for a given conductor size, and only requires two conductors while $\mathrm{AC}$ transmission requires three. 
Thus even though converter stations are very expensive, the cost per kilometer of DC transmission lines is lower. Generally, for distances above about $600 \mathrm{~km}$, HVDC transmission is less expensive to build and operate than AC. The relationship between costs of $\mathrm{AC}$ and $\mathrm{DC}$ transmission lines versus the distance that power must be transmitted is illustrated in Fig-1.

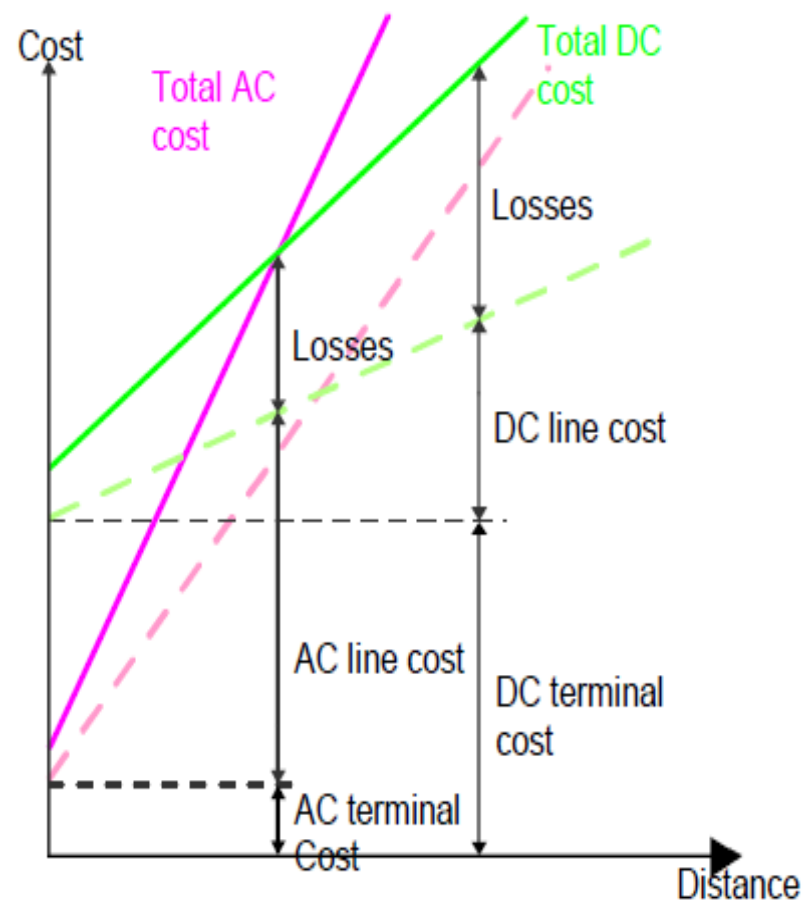

Fig -1: The effect of transmission distance on AC and DC transmission line costs [12]

The dashed lines in this figure illustrate only terminal (converter station for DC, substation for AC) and line costs; the solid lines show that HVDC economics are improved when consideration of the relative line losses of the two technologies are included.

Fig-2 shows the comparison of AC and DC cost curves for an illustrative case. In this example, for a $2000 \mathrm{MW}$ line, AC is less expensive below 700 kilometers, and DC is less expensive above $700 \mathrm{~km}$.

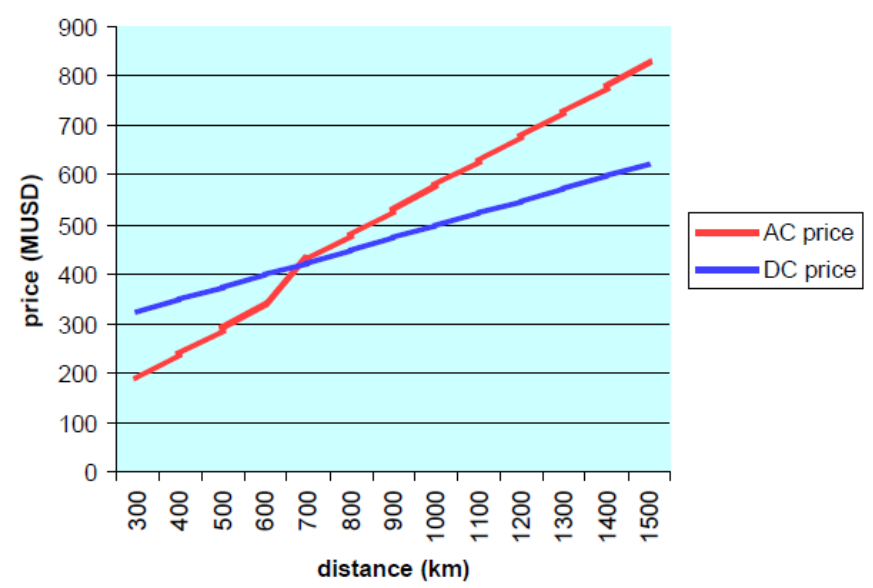

Fig -2: AC and DC line costs for $2000 \mathrm{MW}$ transmission line [12]

\section{Transmitting power under water}

HVDC is preferred for undersea transmission. Undersea cables have a coaxial structure in order to minimize space requirements, but coaxial cables have a high capacitance. This presents a high reactive impedance to $\mathrm{AC}$ transmission, but DC is unaffected by capacitance, and can therefore be used for high capacity, long-distance undersea cables.

\section{Asynchronous interconnections.}

HVDC is a viable alternative when synchronous AC connections are difficult or impossible due to the use of different system frequencies in the systems to be interconnected or other important system differences. As one expert has remarked, "the advent of DC connections has reduced the number of 'islands' that must consider themselves electrically isolated." DC ties between different AC systems deliver some of the benefits of interconnection while avoiding many of the technical problems of synchronous operation. There are two general types of asynchronous interconnection: (1) HVDC transmission over some distance, between two converter stations connected at either end to an AC system. (2) HVDC "back-to-back" interconnection to AC systems on either side, without any intervening transmission. Back-toback connections have sometimes served as a stepping stone to a later full synchronous interconnection. In addition to the three applications above, there are other reasons HVDC interconnections are used. A key one is that HVDC carries more power for a given conductor size. Because of this, in situations where existing transmission capacity is constrained, HVDC is an alternative to an AC transmission upgrade. Conversely, to provide a given transmission capacity, HVDC lines, towers, and rights-of-way can be smaller than a comparable AC system, reducing the line's environmental footprint. Another major advantage is that the solid-state controls of HVDC systems offer complete control over the direction of power flow, without unpredictable loop flows. 
The direction of flow can be reversed, and operating voltages can be reduced if necessary. The track record of HVDC indicates high reliability and availability, and the advantage that in a bipolar system one pole can operate one pole if the other pole is not operational due to maintenance or an outage. Also, HVDC does not increase fault currents in the network it is connected to, so new circuit breakers not required in the rest of the system. HVDC systems, however, are difficult to operate with more than two, or at most three, terminal connections to AC transmission systems, so that HVDC systems are not an optimal choice if power is to be supplied to several intermediate locations along a power line route.

\subsection{Existing HVDC System}

ITAIPU - the world's largest HVDC transmission

Technical Data:

\begin{tabular}{|l|l|}
\hline Commissioning year: & $1984-1987$ \\
\hline Power rating & $3150+3150 \mathrm{MW}$ \\
\hline DC voltage: & $\pm 600 \mathrm{kV}$ \\
\hline Length of overhead DC line: & $785 \mathrm{~km}+805 \mathrm{~km}$ \\
\hline $\begin{array}{l}\text { Main reasons for choosing } \\
\text { HVDC system: }\end{array}$ & $\begin{array}{l}\text { Long distance, } 50 / 60 \mathrm{~Hz} \\
\text { conversion }\end{array}$ \\
\hline
\end{tabular}

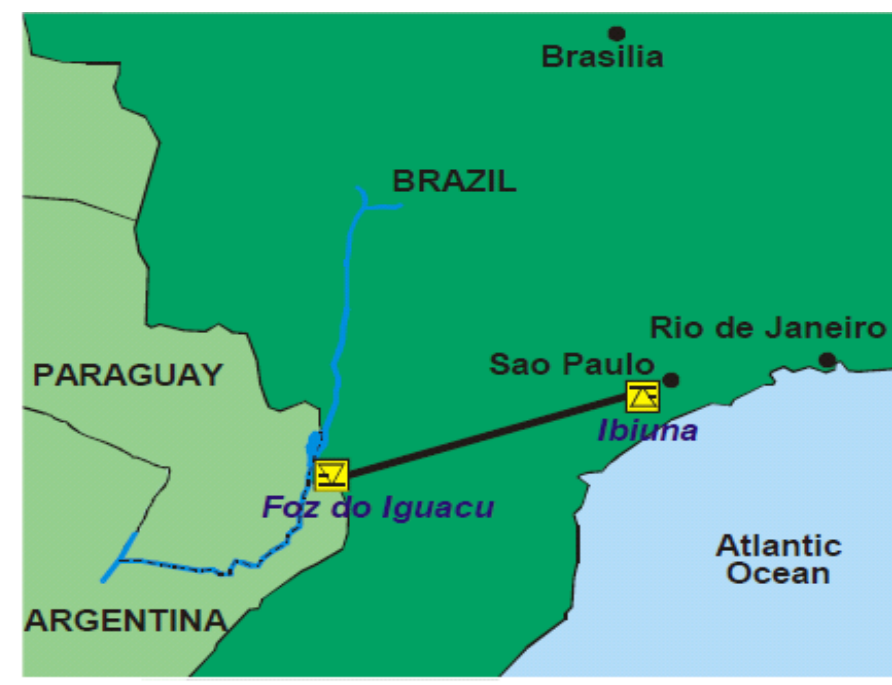

Fig -3: Itaipu HVDC Transmission Project in Brazil [12]

\section{Rihand-Delhi HVDC Transmission, India}

The Rihand-Delhi HVDC transmission is the first commercial long-distance HVDC link in India.

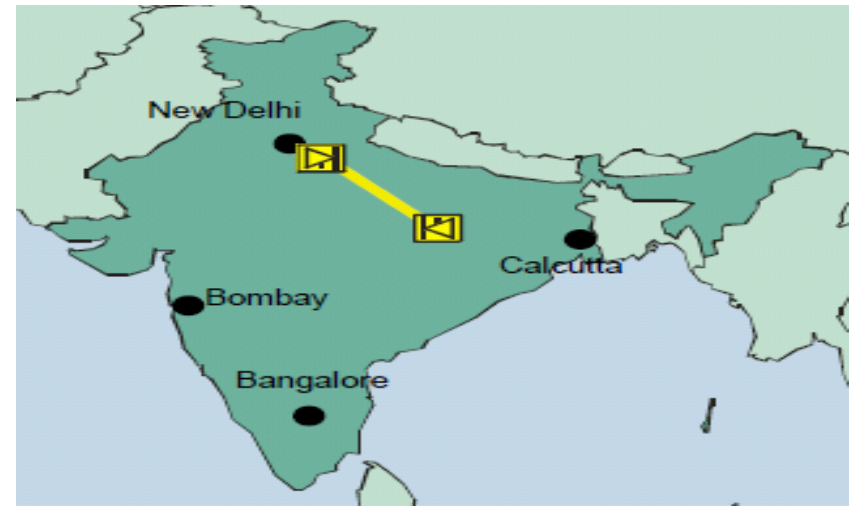

Fig -4: Rihand-Delhi HVDC transmission [12]

\section{Technical Data:}

\begin{tabular}{|l|l|}
\hline Commissioning year: & 1990 \\
\hline Power rating & $1500 \mathrm{MW}$ \\
\hline DC voltage: & $\pm 500 \mathrm{kV}$ \\
\hline Length of overhead DC line: & $814 \mathrm{~km}$ \\
\hline $\begin{array}{l}\text { Main reasons for choosing } \\
\text { HVDC system: }\end{array}$ & Long distance, stability \\
\hline
\end{tabular}

\subsection{Analysis and suggestion}

From Table 8 it is observed that there is large uneven distribution of hydro power resources in SAARC Countries.

Table -8: Comparative table of Hydro resource, Installed capacity and unused amount

\begin{tabular}{|c|c|c|c|}
\hline Country & $\begin{array}{c}\text { Economically } \\
\text { feasible } \\
\text { resource } \\
\text { (Hydro) } \\
\text { MW }\end{array}$ & $\begin{array}{c}\text { Current } \\
\text { Installed } \\
\text { Capacity } \\
\text { (MW) }\end{array}$ & $\begin{array}{c}\text { Unused } \\
\text { resource }\end{array}$ \\
\hline Bhutan & 23,500 & 1,488 & $93.67 \%$ \\
\hline Nepal & 45,610 & 689 & $98.50 \%$ \\
\hline Bangladesh & 546 & 350 & $36 \%$ \\
\hline India & $1,48,700$ & 40,854 & $72.5 \%$ \\
\hline Pakistan & 60,000 & 6,720 & $88 \%$ \\
\hline
\end{tabular}

Though India has higher amount of resources, but they installed small amount of hydroelectric power from its most economical resources. To meet up shortage of electricity India already invest in Bhutan Hydro power development and Importing 60MW power through Kurichu (Bhutan)-Salakhati (India), 336MW through Chukha(Bhutan)-Birpara(India), and 
Exporting $10 \%$ of Nepal Electricity demand through Dhalkebar (Nepal)-Sitamarhi(India)[13].

Bangladesh Government already takes initiation to build Grid connection with india to import 500MW via Back to Back HVDC link Bheramara (Bangladesh) - Baharampur (India). Inherently, Bangladesh has suitable Geographical location with Nepal and Bhutan, Bangladesh yet not taking initiation to invest in huge amount of Hydro resource and International Grid development with mutual assent.

Bhutan has feasible Hydro potential $60000 \mathrm{MW}$, Installed capacity $6720 \mathrm{MW}$, also Nepal has feasible Hydro potential 45610MW and installed capacity 689MW. So, Bangladesh can easily invest in Bhutan and Nepal hydro resources and import surplus power through the proposed link.

\section{A. Chukha (Bhutan) - Birpara (India) -Haldibari (Bangladesh)}

Existing Grid interconnection between Chukha (Bhutan) Birpara (India), 336 MW, 220 KV, 3 ckts. So Bangladesh only need to build approximately $62 \mathrm{~km}$ Back to Back HVDC link Between Birpara (India)-Haldibari (Bangladesh) to connect with Bhutan.

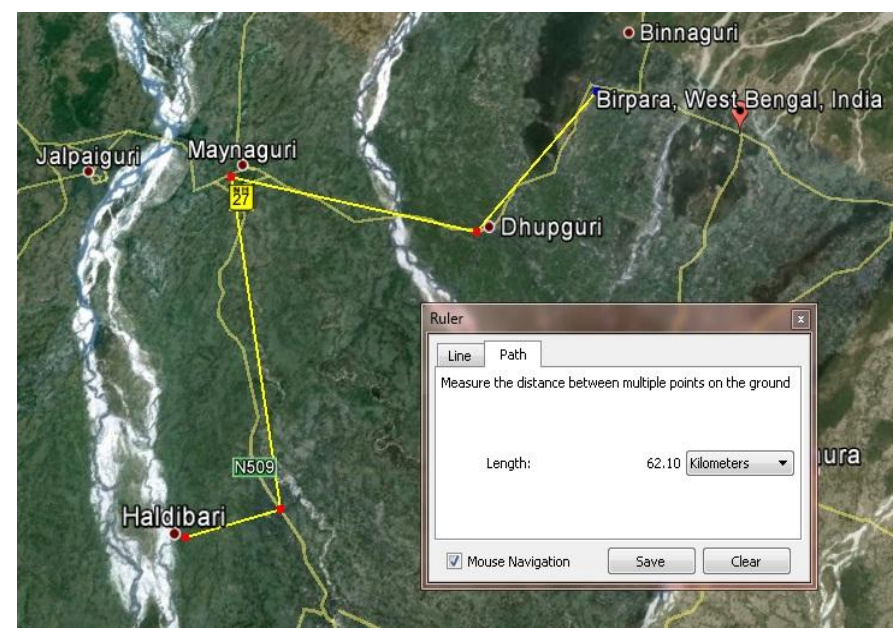

Fig -4: Proposed Back to Back HVDC link between Bhutan and Bangladesh via India.

\section{B. Agartala (Tripura, India) - Akhaura (Bangladesh)}

Existing Grid connection between Kurichu (Bhutan)-Salakhati (Assam, India), 60MW, 132KV line. Indian national Grid connection already exists between Assam (India) - Tripura (India). So, Bangladesh only need approximately $20 \mathrm{~km}$ Back to Back HVDC link between Agartala (Tripura, India) Akhaura (Bangladesh).

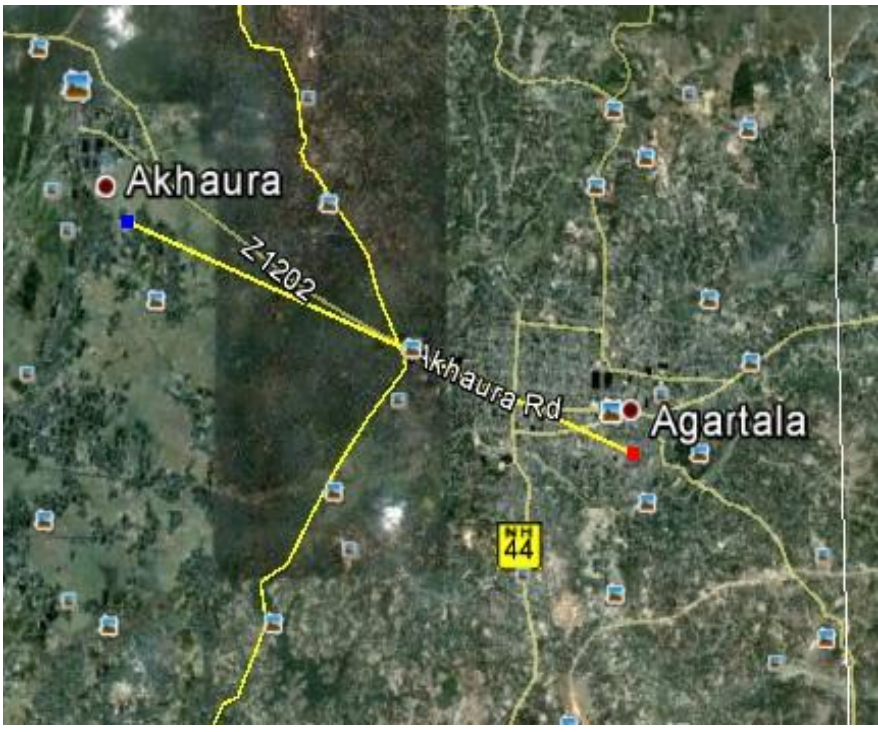

Fig -5: Proposed Back to Back HVDC link between Bhutan and Bangladesh via Tripura, India.

\section{Baharampur (India) - Bheramara (Bangladesh)}

Under Bangladesh-India Electrical Grid Interconnection Project, 125 kilometer long, $400 \mathrm{kV}$ double circuits, 500MW back to back HVDC station at Bheramara (Bangladesh) Bharampur (Bangladesh) is going on, in order to import power from India. India has also power shortage, so to make the going project efficient for future use, Bangladesh can invest in Nepal Hydro power. After, meet up local power demand of Nepal, Surplus Power import to Bangladesh via Dhalkebar (Nepal) - Sitamarhi (India) - Baharampur (India) - Bheramara (Bangladesh).

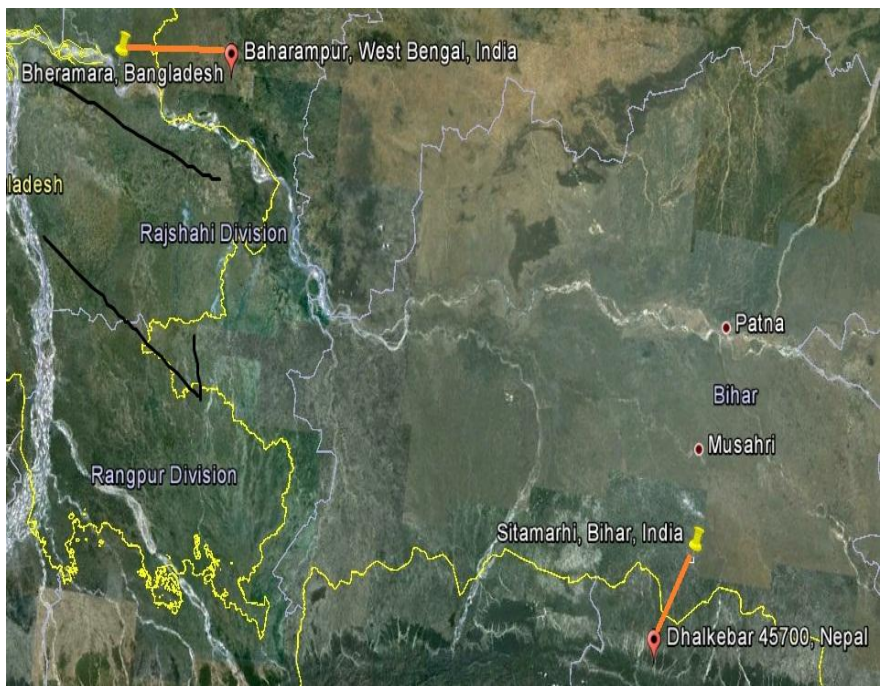

Fig -6: Proposed Back to Back HVDC link between Nepal and Bangladesh. 


\section{BENEFITS OF REGIONAL GRID INTERCONNECTION}

Bhutan and Nepal can develop their economic condition by allowing foreign investment in their Hydro power sector to utilize their unused hydro resources. Bangladesh also can meet their energy shortage by importing Hydro power from Bhutan and Nepal via India. So, India should allow regional Grid interconnection that will make benefit for neighbouring countries as well as for India because some states (Assam, Tripura, Mizoram, Nagaland, Meghalaya, Manipur and Arunachal Pradesh) of India which get an opportunity to connect and share power with India's Major transmission network via Bangladesh. Considering such benefits other SAARC nations can develop regional grid interconnection.

\section{CONCLUSIONS}

Hydro power is the major and more feasible power resource in SAARC Countries. But its most of parts stills unused due to several issues. Now, it's time to take proper mutual initiative for all of SAARC countries for Hydro power resource development. Environment friendly hydro power can solve the problem of shortage of fossil fuels and its environment Hazard. Also, by developing regional grid interconnection with each other whole SAARC nations can be benefitted.

\section{ACKNOWLEDGEMENTS}

The Authors would like to acknowledge "Power Grid Company of Bangladesh, Bangladesh", and "Bangladesh Power Development Board"

\section{REFERENCES:}

[1]. Olivia Gippner, "Discussion Paper, Energy Cooperation in South Asia prospects and Challenges"

[2]. Engr.M. Maher Abaja, "Africa-Europe Electrical interconnection and prospects of worldwide interconnections".

[3]. "Assessment of Renewable Energy Resources of Bangladesh" Mazharul Islam

[4]. "Country paper Renewable Energy interventions in Bangladesh" Tazmilur Rahman, 11-16 March 2007, Beijing, China

[5]. "Overview of Energy policy of Bhutan" Department of Energy ,MoEA, Thimphu, March27, 2009.

[6]. "Nepal Micro Hydropower Development Association" http://www.microhydro.org.np/ nmhda@ntc.net.np nmhdanmhda@gmail.com

[7]. "Wind Energy Potential Assessment In Nepal" B.N. Upreti and Anil Shakyab

[8]. "India's Renewable Energy Sector Potential and Investment Opportunities"

http://www.direc2010.gov.in/pdf/India\%27s-RE-Sector-

Potential-and-Investment- opportunites-SSM.pdf
[9]."Bangladesh renewable energy" http://www.banglapedia.org/httpdocs/HT/R_0175.HTM [10]. "Perspectives on Power Grid Interconnection in Northeast Asia" Felix F. Wu, the University of Hong Kong and University of California at Berkeley.

[11]. "Hydro Scenario" NHPC Limited, A government of India Enterprise,

http://www.nhpc.gov.in/English/Scripts/Hydro_Scenario.aspx [12]. "High Voltage Direct Current (HVDC) Transmission Systems Technology” Review Paper. , From p.7, R. Rudervall, J. Charpentier, and R. Sharma available at http://www.twolf.com/pub/energy/technology_abb.pdf [13]. “Sub-Station Engineering, Design, Concepts \& Computer Applications” Er. R. S. Dahiya.

\section{BIOGRAPHIES:}

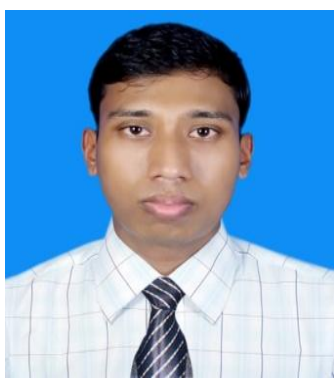

T. H. M. Sumon Rashid received the Bachelor of Science degree in Electrical and Electronic Engineering from the Chittagong University of Engineering \& Technology (CUET), Bangladesh in 2010. He is currently serving as a Lecturer in the Department of EEE, Pabna Science and Technology University (PSTU), Pabna, Bangladesh. His research interests are, in the field of Renewable energy and its Technology, Nanotechnology and Telecommunication. He has published his research work in 2 international journals.

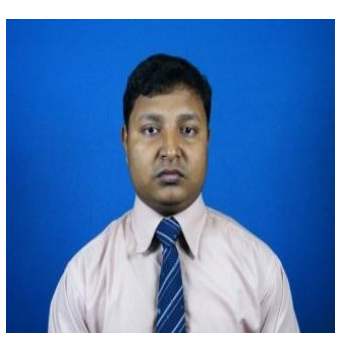

Md. Rabiul Islam received the Bachelor of Science degree in Electrical and Electronic Engineering from the Rajshahi University of Engineering \& Technology (RUET), Bangladesh in 2007. He is currently serving as a Lecturer in the Department of EEE, Pabna Science and Technology University (PSTU), Pabna, Bangladesh. His research interests are, in the field of Renewable energy and its Technology, Nanotechnology and Telecommunication. He has published his research work in 2 international journals. 